\title{
Preservative effects of the combined treatment of slightly acidic electrolyzed water and ice on pomfret
}

\author{
Xiaoling Huang ${ }^{1}$, Songming Zhu ${ }^{1,2}$, Xiaomin Zhou ${ }^{3}$, Jinsong $\mathrm{He}^{4}$, Yong $\mathrm{Yu}^{1}$, Zhangying $\mathrm{Ye}^{1,2^{*}}$ \\ (1. College of Biosystems Engineering and Food Science, Zhejiang University, Hangzhou 310058, China; \\ 2. Ocean Academy, Zhejiang University, Zhoushan 316000, Zhejiang, China; \\ 3. Industrial Enterprise Research Institute of Marine Food Deep Processing, Zhoushan 316101, Zhejiang, China; \\ 4. College of Food Science and Technology, Yunnan Agricultural University, Kunming 650201, China)
}

\begin{abstract}
This study assessed the combined effect of slightly acidic electrolyzed water (SAEW) and slightly acidic electrolyzed water ice (SAEW-ice) on the quality of pomfrets over a period of $18 \mathrm{~d}$ of cold storage at $4^{\circ} \mathrm{C}$. A presoak for $5 \mathrm{~min}$ in SAEW solution $(22 \mathrm{mg} / \mathrm{L})$ was used before the pomfrets were placed on SAEW-ice (pH: 6.45; ORP: $803 \mathrm{mV}$; ACC: $18 \mathrm{mg} / \mathrm{L}$ ); The changes in physicochemical properties (i.e., $\mathrm{pH}$, thiobarbituric acid, total volatile basic nitrogen and texture profile), microbial loads and sensory characteristics were all analyzed. Compared with the tap water (TW) group, the total bacterial counts of the SAEW group significantly decreased by $1.27 \log _{10} \mathrm{CFU} / \mathrm{g}$ after immersion $(p<0.05)$. The shelf life of the pomfrets was prolonged by $9 \mathrm{~d}$ by the combined treatment of SAEW and SAEW-ice during storage at $4{ }^{\circ} \mathrm{C}$. On the 18 th day, the gumminess and chewiness values of the pomfrets in the SAEW+SAEW-ice group were $195 \mathrm{~g}$ and $3.97 \mathrm{~mJ}$, respectively, which were significantly higher than those of the other groups $(p<0.05)$. The results suggested that SAEW+SAEW-ice treatments have great potential as a novel method to maintain the quality and extend the shelf life of pomfrets during refrigerated storage.
\end{abstract}

Keywords: pomfret, slightly acidic electrolyzed water, slightly acidic electrolyzed water ice, storage quality, preservation DOI: $10.25165 /$ j.ijabe.20211401.5967

Citation: Huang X L, Zhu S M, Zhou X M, He J S, Yu Y, Ye Z Y. Preservative effects of the combined treatment of slightly acidic electrolyzed water and ice on pomfret. Int J Agric \& Biol Eng, 2021; 14(1): 230-236.

\section{Introduction}

Pomfret is popular among consumers due to its nutrient-rich features, such as less prickly meat, rich unsaturated fatty acids, and high-quality protein. However, the growth of various spoilage bacteria, which contaminate the aquatic products when they are caught, often accelerate the deterioration of the aquatic product and reduce their quality ${ }^{[1,2]}$. In the circulation process after fishing, the deterioration of the fish quality is mainly reflected in the growth of microorganisms, protein denaturation, lipid oxidation, and a drop in hardness and elasticity ${ }^{[3]}$. Almost 646 million $t$ of aquatic products were produced in 2018 in China, with $51 \%$ of the products coming from seawater ${ }^{[4]}$. Pomfret is not only a kind of marine fish mainly caught from the East China Sea and the South China Sea in China but also an emerging aquaculture species ${ }^{[1,5,6]}$.

To ensure the quality of the aquatic products, a series of approaches have been reported, including low temperature ${ }^{[7]}$, preservative coating $^{[8,9]}$, a modified atmosphere ${ }^{[10]}$, irradiation ${ }^{[11]}$

Received date: $2020-06-24 \quad$ Accepted date: $2020-10-30$

Biographies: Xiaoling Huang, $\mathrm{PhD}$ candidate, research interest: aquacultural engineering, Email: 860071810@qq.com; Songming Zhu, PhD, Professor, research interest: aquacultural engineering, Email: sywshuo@163.com; Xiaomin Zhou, MS, research interest: biochemical engineering; Email: xiaominzhou@, 126.com; Jinsong He, PhD, Associate Professor, research interest: food quality and safety, Email: hejinsong@mail.tsinghua.edu.cn; Yong Yu, PhD, Associate Professor, research interest: aquacultural engineering, Email: yyuzju@zju.edu.cn.

*Corresponding author: Zhangying Ye, $\mathrm{PhD}$, Professor, research interest: agricultural engineering and aquacultural engineering. College of Biosystems Engineering and Food Science, Zhejiang University, Hangzhou 310058, China. Tel: +86-15168310563, Email: yzyzju@zju.edu.cn. and high pressure ${ }^{[11]}$. However, due to the limitations of most methods, low-temperature preservation is still the main tool to extend the shelf-life of aquatic products ${ }^{[12,13]}$.

Slightly acidic electrolyzed water (SAEW), a type of electrolyzed water (EW), contains the main bactericidal component hypochlorite produced by electrolysis of a certain concentration of electrolytes such as sodium chloride and dilute hydrochloric acid ${ }^{[14]}$ SAEW is promoted widely in food preservation for its superiority in its broad spectrum of antimicrobial activity, low cost of production, convenient application, and environment-friendly usage. Furthermore, related research has confirmed that SAEW can kill Listeria monocytogenes ${ }^{[15]}$, Escherichia coli ${ }^{[16]}$, Salmonella enterica $^{[17]}$ and other natural microbiota on the surface of food $^{[16,18]}$.

As a substitute for tap water ice, electrolyzed water ice has also been used to ensure the freshness of the aquatic products. Zhang et al. ${ }^{[19]}$ combined the ice-glazing with weakly acidic electrolyzed water (WAEW) and modified atmosphere packaging (MAP) in the preservation of frozen shrimp, which was shown to be highly effective in maintaining its physicochemical properties. The quality of the aquatic product can be significantly improved when it is placed on or in ice, which was also confirmed by Xuan et al. ${ }^{[20]}$ However, as far as we know, there are relatively few studies on the combined effect of SAEW and SAEW-ice on the preservation of pomfrets. To reduce the quality degradation caused by endogenous enzymes and spoilage bacteria, this study investigated the efficacy of different treatment groups (SAEW/SAEW-ice) on microbial loads, physicochemical $(\mathrm{pH}$, thiobarbituric acid, total volatile basic nitrogen, and texture) parameters, sensory characteristics, and the shelf life time of pomfrets during refrigeration (Figure 1). 


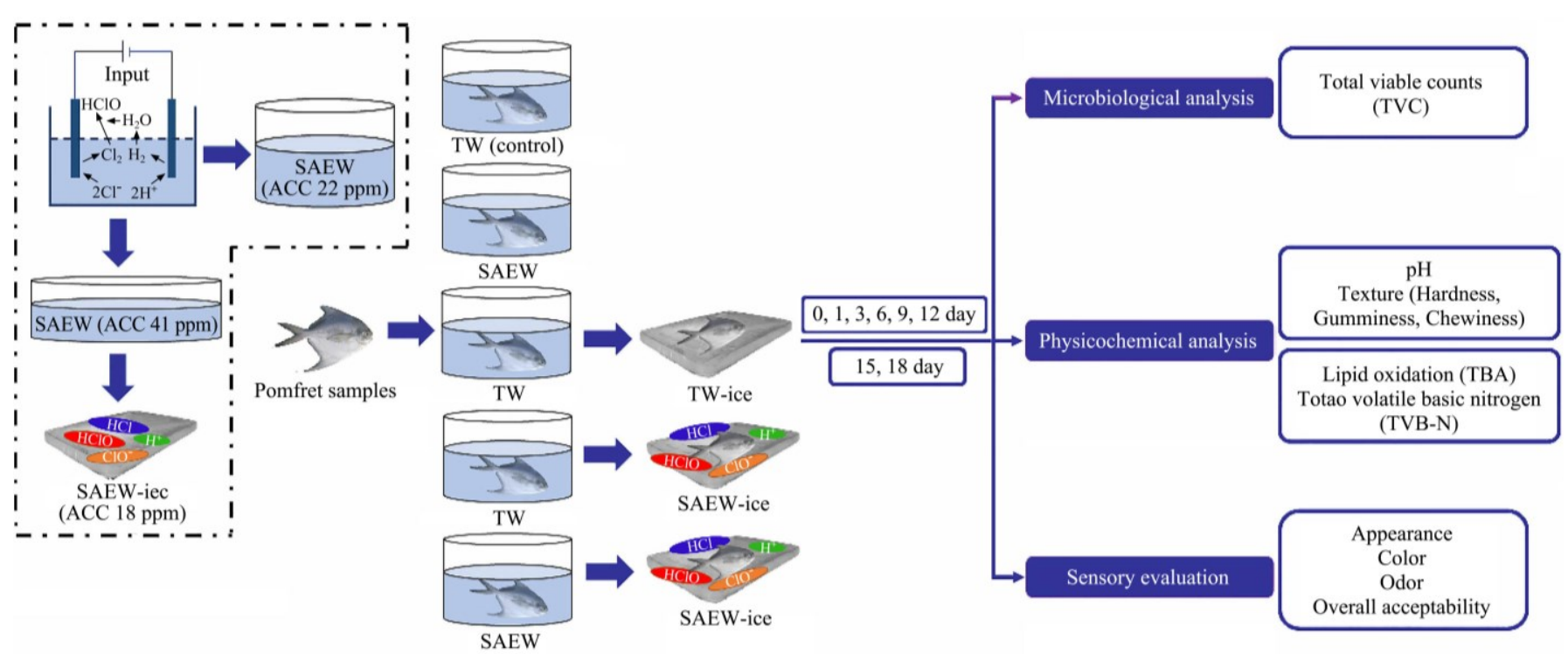

Figure 1 Schematic diagram of sterilizing pomfrets with various treatments

\section{Materials and methods}

\subsection{Treatments of silver pomfret}

Silvery pomfrets were provided by the Zhejiang Industrial Group Co., Ltd, and transferred to the lab on ice from the Zhejiang Province of China within $12 \mathrm{~h} .90 \mathrm{~g}$ of fresh pomfrets was chosen to be thoroughly washed with ice water and drained with tissue papers. The pomfrets were randomly divided into five groups according to the experimental design (three samples in each group): pomfrets immersed in tap water (TW) for 5 min (control); pomfrets immersed in SAEW for $5 \mathrm{~min}$; pomfrets immersed in TW for $5 \mathrm{~min}$ and placed on tap water ice (TW-ice); pomfrets immersed in TW for $5 \mathrm{~min}$ and placed on slightly acidic electrolyzed water ice (SAEW-ice); pomfrets immersed in SAEW for 5 min and placed on SAEW-ice (SAEW+SAEW-ice) (Table 1). After the immersions, all the treated fish were dried by a fan. The pomfret samples were then individually packaged and refrigerated (approximately $4^{\circ} \mathrm{C}$ ) for a period up to $18 \mathrm{~d}$ for subsequent quality assessment. The microbiological, physicochemical, and sensorial properties of random samples were analyzed at days $0,1,3,6,9,12,15$, and 18 . Furthermore, the SAEW ice and TW ice were replaced every $24 \mathrm{~h}$. All the experiments were conducted in triplicate.

Table 1 Abbreviations of each group

\begin{tabular}{|c|c|}
\hline Abbreviation & Treatment \\
\hline $\begin{array}{l}\text { TW group } \\
\text { (control group) }\end{array}$ & $\begin{array}{l}\text { Pomfrets were immersed in tap water (TW) for } 5 \mathrm{~min} \\
\text { before dried }\end{array}$ \\
\hline SAEW group & $\begin{array}{l}\text { Pomfrets were immersed in slightly acidic electrolyzed } \\
\text { water (SAEW) for } 5 \mathrm{~min} \text { before dried }\end{array}$ \\
\hline TW-ice group & $\begin{array}{l}\text { Pomfrets were immersed in tap water (TW) for } 5 \text { min } \\
\text { before dried and placed on tap water ice (TW-ice) }\end{array}$ \\
\hline SAEW-ice group & $\begin{array}{l}\text { Pomfrets were immersed in tap water (TW) for } 5 \mathrm{~min} \\
\text { before dried and placed on slightly acidic electrolyzed } \\
\text { water ice (SAEW-ice) }\end{array}$ \\
\hline $\begin{array}{l}\text { SAEW+SAEW-ice } \\
\text { group }\end{array}$ & $\begin{array}{l}\text { Pomfrets were immersed in slightly acidic electrolyzed } \\
\text { water (SAEW) for } 5 \mathrm{~min} \text { before dried and placed on } \\
\text { slightly acidic electrolyzed water ice (SAEW+SAEW-ice) }\end{array}$ \\
\hline
\end{tabular}

2.2 Preparation and physiochemical property measurements of SAEW and SAEW ice

SAEW was prepared by electrolysis of a $6 \% \mathrm{HCl}$ solution using a generator (HD-240L, Fuqiang-Want Sanitary Accessories Ltd, Shanghai, China) with a nonmembrane electrolytic chamber at a voltage of $220 \mathrm{~V}$. The SAEW-ice was prepared by freezing the
SAEW solution immediately at $-20^{\circ} \mathrm{C}$ overnight in the boxes for storing the samples after generation. The SAEW and SAEW-ice were prepared on the day of the experiments and used within $1 \mathrm{~h}$ of production. The physicochemical properties of the SAEW used to sanitize the samples, the SAEW used to prepare the SAEW-ice, and the SAEW-ice were separately determined immediately after generation. In addition, a group of ice samples (100 g) was evaluated after being completely melted in a sealed bag in an $80^{\circ} \mathrm{C}$ water bath. The $\mathrm{pH}$ and oxidation reduction potential (ORP) values were measured by a multifunctional $\mathrm{pH} / \mathrm{ORP}$ meter bearing $\mathrm{pH}$ and ORP electrodes (PHS-C, INESA Scientific Instrument Co., Ltd, Shanghai, China). The available chlorine concentration (ACC) was evaluated by a colorimetric method using a digital chlorine test kit (HI96771, HANNA Instrument Co., Ltd, Italy) with a detection range of $0-500 \mathrm{mg} / \mathrm{L}$. All measurements were carried out in triplicate (data shown in Table 2).

Table 2 Properties of SAEW (soak solution),SAEW-ice and melted SAEW-ice

\begin{tabular}{cccc}
\hline Property & SAEW (soak solution) & SAEW-ice (prepared) & SAEW-ice (melted) \\
\hline $\mathrm{ACC} / \mathrm{mg} \cdot \mathrm{L}^{-1}$ & $22 \pm 0$ & $41 \pm 1.00$ & $18 \pm 0$ \\
$\mathrm{pH}$ value & $6.42 \pm 0.03$ & $5.77 \pm 0.09$ & $6.49 \pm 0.02$ \\
$\mathrm{ORP} / \mathrm{mV}$ & $822 \pm 2$ & $868 \pm 8$ & $803 \pm 6$ \\
\hline
\end{tabular}

Note: ACC: Available Chlorine Concentration, mg/L; ORP: Oxidation Reduction Potential, $\mathrm{mV}$.

\subsection{Microbiological analysis}

The number of the bacteria population was determined by analyzing $10 \mathrm{~g}$ of pomfret samples at each sampling time point. The sliced samples were homogenized with $90 \mathrm{~mL}$ of sterile $0.9 \%$ $(\mathrm{w} / \mathrm{v})$ normal saline (NS) for $90 \mathrm{~s}$ in a filtered stomacher bag by using a homogenizer (JYD-400, Shanghai Zhisun Equipment Co., Ltd, Shanghai, China). The homogenized solutions were serially diluted (1: 10), and $0.1 \mathrm{~mL}$ of the desired dilution of each group was used for plating on plate count agar (PCA, Baisi Bio-Technology Co., Ltd., Hangzhou, Zhejiang, China). All the plates were incubated at $37^{\circ} \mathrm{C}$ for $48 \mathrm{~h}$, and all the counts are shown as $\log _{10} \mathrm{CFU} / \mathrm{g}$ sample, performed in duplicate.

\subsection{Determination of $\mathbf{p H}$}

The $\mathrm{pH}$ value was determined using a $\mathrm{pH}$ meter (Testo AG205, Lenzkirch, Germany) by inserting an electrode into the dorsal muscle. Each sample was measured six times to reduce errors. 


\subsection{Determination of TBARS}

The TBA was determined in duplicate measurements according to the method of Buege, Aust ${ }^{[21]}$. The samples were homogenized with 5 volumes (w/v) of 2-thiobarbituric acid (TBA) reagent $(0.375 \% \mathrm{w} / \mathrm{v}$ TBA, $15 \% \mathrm{w} / \mathrm{v}$ TCA, and $0.25 \mathrm{~mol} / \mathrm{L} \mathrm{HCl})$. The mixture was heated $10 \mathrm{~min}$ and then centrifuged $(4500 \mathrm{r} / \mathrm{min}$, $25 \mathrm{~min}, 4^{\circ} \mathrm{C}$ ), and the absorbance was measured at $532 \mathrm{~nm}$. The concentration of TBARS in the fish was expressed as mg of malondialdehyde (MDA)/100 g sample after comparing it with an MDA standard.

\subsection{Determination of total volatile basic nitrogen}

The measurement of total volatile basic nitrogen (TVBN) was carried out by the method of $\mathrm{Wu}$ et al. ${ }^{[22]}$ and Foss ${ }^{[23]}$, with slight modification. Briefly, $3 \mathrm{~g}$ of the minced sample was blended with $100 \mathrm{~mL}$ ultrapure water for $30 \mathrm{~min}$ before adding $1 \mathrm{~g}$ of $\mathrm{MgO}$. The TVBN values were measured with a Kjeltec 2300 (FOSS, Hiller, Denmark) and expressed in $\mathrm{mg}$ TVBN/100 $\mathrm{g}$ of fish meat. TVBN was calculated with the following equation:

$$
\mathrm{TVBN}=\frac{\left(V_{1}-V_{2}\right) \times c \times 14}{m \times \frac{3}{100}} \times 100
$$

where, $V_{1}$ and $V_{2}$ respectively represented the volumes of hydrochloric acid added to the sample groups and the blank group, $\mathrm{mL}$; $\mathrm{c}$ was the concentration of hydrochloric acid, $\mathrm{mol} / \mathrm{L}$; $\mathrm{m}$ was the weight of the samples, g, with the results expressed as mg TVBN/100 g.

\subsection{Texture analyses}

The texture parameters of hardness, gumminess, and chewiness of the pomfrets were determined using a Brookfield CT3 texture analyzer (Brookfield Engineering Laboratories, INC. Middleboro, Massachusetts, USA) equipped with a $5 \mathrm{~mm}$ cylindrical probe $(\mathrm{P} / 5)$. The muscle was cut from the fish loin, which was then placed on the flat plate of the texturometer. Two consecutive cycles at $50 \%$ compression were applied to construct the texture profile analysis parameters. TPA was performed under the following conditions: constant test speed, $1.0 \mathrm{~mm} / \mathrm{s}$; hold time between cycles, $5 \mathrm{~s}$; and trigger force, $5 \mathrm{~g}$.

\subsection{Sensory evaluation}

The sensory evaluation was carried out by trained judges using a 9-point descriptive analysis according to the method of $\mathrm{Wu}$ et al. ${ }^{[22]}$. Seven trained panelists judged the sensory properties of the pomfret samples based on the appearance, color, smell, and overall acceptability. And the sensory scores were the mean of the four indicators. The samples with a score above four were considered acceptable.

\subsection{Statistical analysis}

All the experiments were performed in triplicate, and the data were expressed as the means \pm SD Statistical analyses were carried out with the IBM SPSS statistical software (SPSS 20.0 for windows, SPSS Inc., Chicago, IL, USA). ANOVA $(p<0.05)$ and Duncan's test were used to compare the means with standard deviations and to assess the difference among the different treatment groups.

\section{Results and discussion}

\subsection{Microbiological analysis}

The presence of microorganisms in aquatic products is one of the main reasons for spoilage and deterioration. As shown in Figure 2, the total viable counts (TVC) of the five groups significantly increased $(p<0.05)$. The initial TVC value of the pomfrets treated with SAEW prominently decreased to $2.88 \log _{10}$
$\mathrm{CFU} / \mathrm{g}$, compared to $4.15 \log _{10} \mathrm{CFU} / \mathrm{g}$ in those samples treated with TW $(p<0.05)$. A TVC value lower than $7 \log _{10} \mathrm{CFU} / \mathrm{g}$ is considered fresh in fish ${ }^{[24]}$. In this study, the TVC of the TW-, SAEW-, and TW-ice-treated groups reached this limitation on the 9th, 12th, and 18th day, respectively, while that of the SAEW-ice-treated group was lower than this threshold at the end of the storage period. As expected, the pomfrets in the TW group had the highest TVC value, followed by the SAEW, TW-ice, SAEW-ice, and SAEW+SAEW-ice groups during the storage period. To a certain extent, our results indicated that SAEW, TW-ice, and SAEW-ice induced an effective delay in bacterial growth, as demonstrated by Zhang et al. ${ }^{[19]}$ and Xuan et al. ${ }^{[20]}$. Moreover, the combination of SAEW and SAEW-ice allowed for good retention of the fish quality, which is inferred from the lowest TVC value of the combination treatment among the five groups. Several previous studies reported that SAEW and SAEW-ice showed antimicrobial activity against bacteria ${ }^{[20,25]}$.

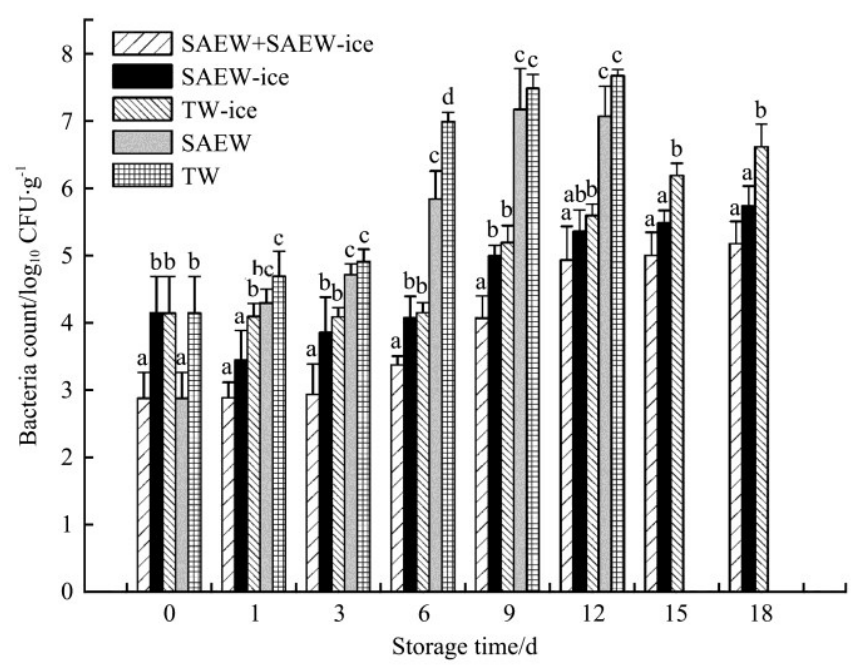

Note: Different lowercase letters at the same storage time showed a significant difference at $p<0.05$.

Figure 2 Changes in total viable bacteria count (TVC) of pomfrets with different treatments during cold storage

\section{2 pH values}

Changes in $\mathrm{pH}$ value during the storage of the five groups are exhibited in Figure 3. The initial $\mathrm{pH}$ value of the pomfret samples treated with TW on day 0 was approximately 6.74. This result was higher than the findings of Wu et al. ${ }^{[12]}$, which showed a $\mathrm{pH}$ of approximately 6.34. Differences in the initial $\mathrm{pH}$ might be related to diet, activity levels, farming season, and stress during fishing. On the 1st day, a decreasing trend in $\mathrm{pH}$ in the SAEW, TW-ice, SAEW-ice, and SAEW+SAEW-ice groups was observed, which might be explained by the decrease in the energy reserves and the accumulation of lactic acid or other compounds resulting from glycolysis $^{[20,22]}$. Similar results were also found by $\mathrm{Xu}$ et al. ${ }^{[26]}$. Nevertheless, the $\mathrm{pH}$ values of all pomfret samples increased gradually over time and then became slightly alkaline or close to neutral. An increasing trend observed in all samples after $1 \mathrm{~d}$ indicated the occurrence of spoilage, which induces the accumulation of ammonia compounds ${ }^{[27]}$. Though the $\mathrm{pH}$ values of these samples increased at different rates, the TW group demonstrated the highest rate, and the SAEW+SAEW-ice group demonstrated the lowest rate. Accordingly, by day 12, the $\mathrm{pH}$ values reached 7.53, 7.18, 7.03, 6.92, and 6.84 for the TW, SAEW, TW-ice, SAEW-ice, and SAEW+SAEW-ice groups, respectively. During the storage period of $15-18 \mathrm{~d}$, the $\mathrm{pH}$ values of the fish treated with the combination of SAEW and SAEW-ice were 
significantly $(p<0.05)$ lower than those of the fish with the individual treatments (SAEW-ice or SAEW). Since the increase in $\mathrm{pH}$ value is caused by the accumulation of various alkaline substances produced by the endogenous enzymes and microorganisms in the sample ${ }^{[20,28]}$, we inferred that the lowest $\mathrm{pH}$ value in the SAEW+SAEW-ice treatment might demonstrate its great potential for maintaining the quality of pomfrets in cold storage.

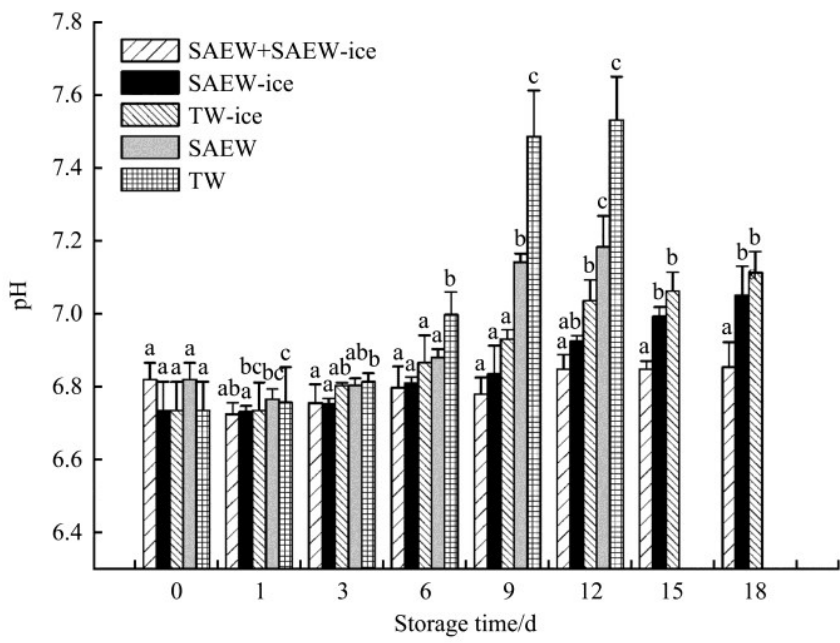

Note: Different lowercase letters at the same storage time showed a significant difference at $p<0.05$.

Figure 3 Changes in $\mathrm{pH}$ values of pomfrets with different treatments during cold storage

\subsection{Thiobarbituric acid value}

Mean TBA determinations of the five groups over the period of storage at $4{ }^{\circ} \mathrm{C}$ are shown in Figure 4 . Obviously, the TBA of the TW group rapidly increased from $0.19 \mathrm{mg} / 100 \mathrm{~g}$ to $3.38 \mathrm{mg} / 100 \mathrm{~g}$ on the 12th storage day, whereas lower values of $0.82 \mathrm{mg} / 100 \mathrm{~g}$, $1.02 \mathrm{mg} / 100 \mathrm{~g}, 1.67 \mathrm{mg} / 100 \mathrm{~g}$ and $2.88 \mathrm{mg} / 100 \mathrm{~g}$, respectively, were obtained for the SAEW+SAEW-ice, SAEW-ice, TW-ice, and SAEW groups $(p<0.05)$. At the end of the $18 \mathrm{~d}$ of storage, the TBA in the pomfrets was found to be $1.98 \mathrm{mg} / 100 \mathrm{~g}, 1.79 \mathrm{mg} / 100 \mathrm{~g}$ and $1.18 \mathrm{mg} / 100 \mathrm{~g}$, respectively, when treated with TW, SAEW-ice and SAEW+SAEW-ice, which demonstrates a significantly higher ability for restraining TBA increases $(p<0.05)$. Meanwhile, it was considered that ice could effectively restrain the increase in the TBA value, as clarified by Xuan et al. ${ }^{[20]}$. Furthermore, the SAEW pretreatment combined with SAEW-ice dramatically maintained a low TBA value at the end of storage, compared with individual SAEW-ice treatment $(p<0.05)$.

As a measure of fish quality, a higher TBA value reveals a higher degree of oxidation of aquatic products ${ }^{[29,30]}$. According to the results of this study, we could infer that the combination of SAEW and SAEW-ice treatment might slow down lipid oxidation. These results were similar to those reported by Luan et al. ${ }^{[24]}$, who stated that a chitosan coating combined with electrolyzed oxidizing water effectively slowed the increase in lipid oxidation and prolonged the shelf life of hairtail. Xuan et al. ${ }^{[20]}$ also found the preservation effectiveness of SAEW-ice in inhibiting lipid oxidation and eliminating off-flavors.

\subsection{Total volatile basic nitrogen value}

Figure 5 presents the TVBN of the pomfret samples influenced by the treatments of the five groups during storage at $4{ }^{\circ} \mathrm{C}$. The increase in TVBN might be related to the conversion of protein and nonprotein nitrogen compounds to alkaline nitrogenous compounds by bacteria and endogenous enzymes, which are considered to be an indicator of fish freshness and quality ${ }^{[20,31]}$. On day 0 , the TVBN values were $7.00 \mathrm{mg} / 100 \mathrm{~g}$ and $6.84 \mathrm{mg} / 100 \mathrm{~g}$ after immersion in TW and SAEW, respectively, similar to the results of $7.25 \mathrm{mg} / 100 \mathrm{~g}$ reported by $\mathrm{Wu}$ et al. ${ }^{[12]}$ Though different TVBN values exist in fishery products, a level of $30 \mathrm{mg} / 100 \mathrm{~g}$ for the TVBN value of fresh fish has been considered as the upper limit for fishery products acceptable by consumers ${ }^{[12]}$. During storage at $4^{\circ} \mathrm{C}$, the TVBN values in all samples increased continually. However, the increase in TVBN was much slower in all samples placed on ice $(p<0.05)$, with the SAEW and SAEW-ice combined treatment showing the slowest increasing rate. In addition, unacceptable samples appeared on the 3rd, 9th, and 18th day in the TW, SAEW, and TW-ice groups, respectively. During the storage period of $18 \mathrm{~d}$, the TVBN values of the pomfrets in the combination treatment group were slightly but insignificantly $(p>0.05)$ lower than those of the pomfrets in the individual SAEW-ice treatment group, which might be attributed to the short storage time being unable to show the effects of SAEW pretreatment.

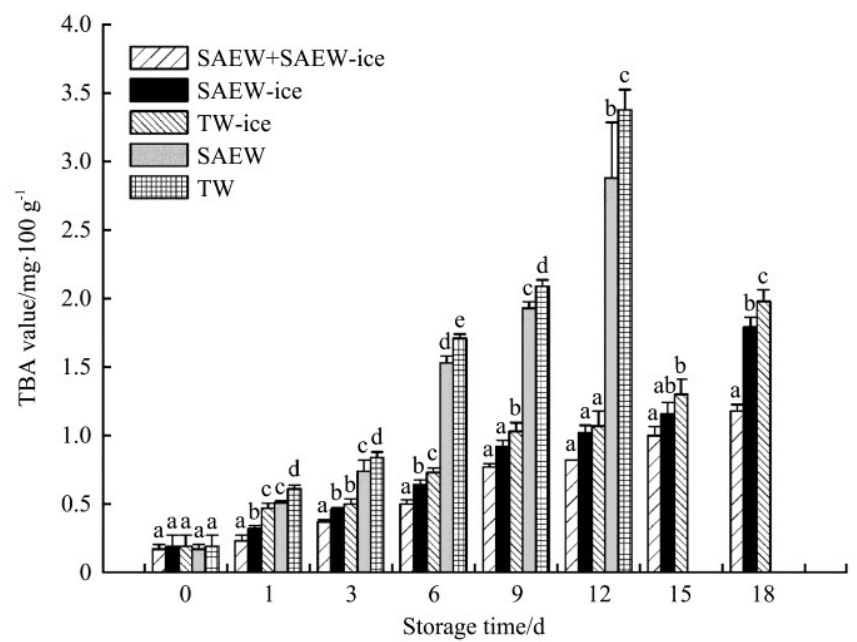

Note: Different lowercase letters at the same storage time showed a significant difference at $p<0.05$.

Figure 4 Changes in TBA values of pomfrets with different treatments during cold storage

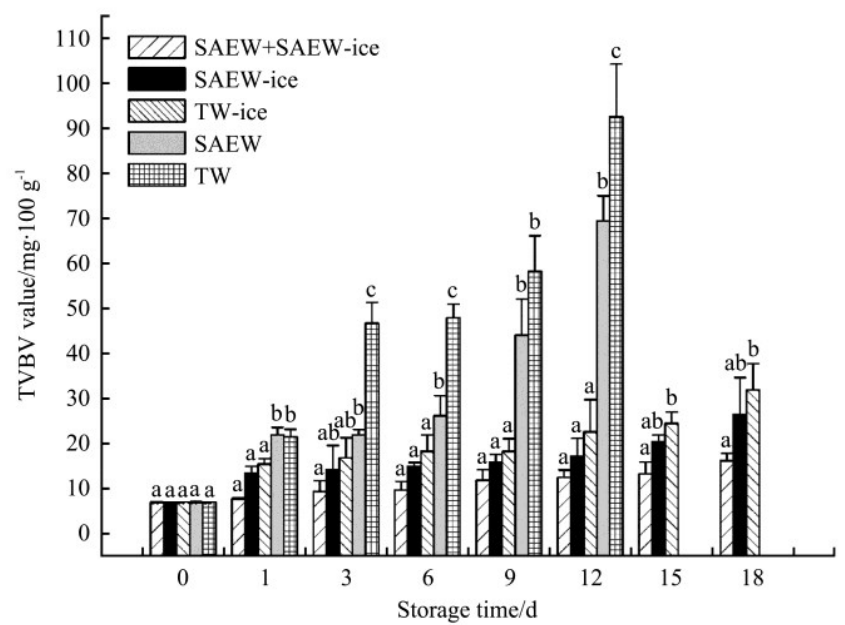

Note: Different lowercase letters at the same storage time showed a significan difference at $p<0.05$.

Figure 5 Changes in TVBN values of pomfrets with different treatments during cold storage

\subsection{Texture analysis}

Hardness is the force required for fish to achieve a certain deformation, which is a more significant indicator of human tactile 
sensory analysis ${ }^{[32]}$. Gumminess is expressed as the product of hardness and cohesion numerically, which has a positive correlation with fish cohesion, elasticity, and fatty properties, reflecting the tightness of the internal tissue state of the muscle. The chewiness is closely related to muscle hardness and elasticity affected by the collagen content in the fish ${ }^{[18,26]}$. From the testing results (Table 3 ), the hardness, gumminess, and chewiness of all the samples changed notably during storage $(p<0.05)$. At the same time, statistically significantly higher $(p<0.05)$ values of the gumminess and chewiness in the SAEW + SAEW-ice group were found. The loss of hardness was $69 \%$ and $42 \%$ in the TW group and the SAEW group on the 12 th day, and $17 \%, 28 \%$, and $34 \%$ in the SAEW+SAEW-ice group, SAEW-ice group, and TW-ice group, respectively. Furthermore, the lowest level of gumminess in the five groups on day 12 was $53 \mathrm{~g}$, which was much lower than the value of gumminess in the SAEW+SAEW-ice group on day 18 , reflecting that the combined treatment had a desirable effect on the gumminess properties during cold storage. The values of chewiness declined mostly in the TW group, followed by the SAEW-, TW-ice-, SAEW-ice-, and SAEW+SAEW-ice-treated groups. The initial value of chewiness of the pomfrets was $5.87 \mathrm{~mJ}$, which fell to $1.63 \mathrm{~mJ}, 2.73 \mathrm{~mJ}, 3.07 \mathrm{~mJ}, 4.00 \mathrm{~mJ}$, and $4.33 \mathrm{~mJ}$ on day 12 in the TW, SAEW, TW-ice, SAEW-ice, and SAEW+SAEW-ice groups, respectively. Finally, the value of chewiness decreased to $2.37 \mathrm{~mJ}, 2.7 \mathrm{~mJ}$ and $3.97 \mathrm{~mJ}$ at the end of the 18-day storage period in the TW-ice, SAEW-ice, and SAEW+SAEW-ice groups, respectively. Accordingly, the SAEW+SAEW-ice treatments obviously inhibited texture deterioration compared to other groups. Noticeably, the similar primary texture within $1 \mathrm{~d}$ between the SAEW and the TW-ice groups might indicate that SAEW pretreatment could replace TW-ice for a short time without ice.

Table 3 Changes in texture properties of pomfrets with different treatments during cold storage

\begin{tabular}{|c|c|c|c|c|c|c|c|c|}
\hline \multirow{2}{*}{ Analyze parameters } & \multicolumn{8}{|c|}{ Days of storage } \\
\hline & 0 & 1 & 3 & 6 & 9 & 12 & 15 & 18 \\
\hline \multicolumn{9}{|c|}{ Hardness/g } \\
\hline SAEW+SAEW-ice & $600 \pm 50^{\mathrm{aA}}$ & $593 \pm 23^{\mathrm{aA}}$ & $596 \pm 58^{\mathrm{aA}}$ & $552 \pm 36^{\mathrm{aAB}}$ & $532 \pm 28^{\mathrm{aAB}}$ & $499 \pm 15^{\mathrm{aB}}$ & $449 \pm 44^{\mathrm{aC}}$ & $383 \pm 29^{\mathrm{aD}}$ \\
\hline SAEW-ice & $602 \pm 28^{\mathrm{aA}}$ & $572 \pm 12^{\mathrm{aAB}}$ & $482 \pm 48^{\mathrm{bBC}}$ & $475 \pm 48^{\mathrm{abBC}}$ & $443 \pm 89^{\mathrm{abC}}$ & $431 \pm 95^{\mathrm{abC}}$ & $403 \pm 96^{\mathrm{aC}}$ & $341 \pm 38^{\mathrm{abD}}$ \\
\hline TW-ice & $602 \pm 28^{\mathrm{aA}}$ & $443 \pm 11^{\mathrm{bBC}}$ & $486 \pm 31^{\mathrm{bB}}$ & $449 \pm 69^{\mathrm{bcBC}}$ & $438 \pm 24^{\mathrm{bBCD}}$ & $395 \pm 33^{\mathrm{bCD}}$ & $377 \pm 29^{\mathrm{aD}}$ & $310 \pm 15^{\mathrm{bE}}$ \\
\hline SAEW & $595 \pm 58^{\mathrm{aA}}$ & $457 \pm 62^{\mathrm{bB}}$ & $373 \pm 63^{\mathrm{cBC}}$ & $365 \pm 17^{\mathrm{cdBC}}$ & $349 \pm 49^{\mathrm{cC}}$ & $347 \pm 35^{\mathrm{bC}}$ & & \\
\hline TW & $602 \pm 28^{\mathrm{aA}}$ & $432 \pm 30^{\mathrm{bB}}$ & $334 \pm 58^{\mathrm{cC}}$ & $333 \pm 57^{\mathrm{dC}}$ & $271 \pm 20^{\mathrm{cC}}$ & $188 \pm 11^{\mathrm{cD}}$ & & \\
\hline \multicolumn{9}{|c|}{ Gumminess/g } \\
\hline SAEW+SAEW-ice & $304 \pm 24^{\mathrm{aA}}$ & $282 \pm 14^{\mathrm{aA}}$ & $277 \pm 14^{\mathrm{aA}}$ & $257 \pm 41^{\mathrm{aAB}}$ & $217 \pm 8^{\mathrm{aB}}$ & $208 \pm 38^{\mathrm{aB}}$ & $204 \pm 21^{\mathrm{aB}}$ & $195 \pm 35^{\mathrm{aB}}$ \\
\hline SAEW-ice & $305 \pm 8^{\mathrm{aA}}$ & $276 \pm 13^{\mathrm{aAB}}$ & $246 \pm 20^{\mathrm{abBC}}$ & $216 \pm 21^{\mathrm{abCD}}$ & $186 \pm 27^{\mathrm{aDE}}$ & $171 \pm 20^{\mathrm{aDE}}$ & $153 \pm 48^{\mathrm{aEF}}$ & $117 \pm 9^{\mathrm{bF}}$ \\
\hline TW-ice & $305 \pm 8^{\mathrm{aA}}$ & $229 \pm 16^{\mathrm{bB}}$ & $215 \pm 9^{\mathrm{bcBC}}$ & $194 \pm 26^{\mathrm{bcCD}}$ & $165 \pm 13^{\mathrm{abDE}}$ & $148 \pm 8^{\mathrm{aE}}$ & $138 \pm 19^{\mathrm{aE}}$ & $106 \pm 17^{\mathrm{bF}}$ \\
\hline TW & $305 \pm 8^{\mathrm{aA}}$ & $213 \pm 13^{\mathrm{bB}}$ & $179 \pm 24^{\mathrm{dBC}}$ & $140 \pm 44^{\mathrm{cCD}}$ & $116 \pm 10^{\mathrm{bD}}$ & $53 \pm 2^{\mathrm{bE}}$ & & \\
\hline \multicolumn{9}{|c|}{ Chewiness/mJ } \\
\hline SAEW+SAEW-ice & $5.87 \pm 0.42^{\mathrm{aA}}$ & $5.67 \pm 0.21^{\mathrm{aAB}}$ & $5.37 \pm 0.12^{\mathrm{aAB}}$ & $4.87 \pm 0.58^{\mathrm{aB}}$ & $4.87 \pm 0.49^{\mathrm{aC}}$ & $4.33 \pm 0.78^{\mathrm{aC}}$ & $4.17 \pm 0.42^{\mathrm{aC}}$ & $3.97 \pm 0.61^{\mathrm{aC}}$ \\
\hline SAEW-ice & $5.87 \pm 0.90^{\mathrm{aA}}$ & $5.63 \pm 0.15^{\mathrm{aA}}$ & $5.30 \pm 0.20^{\mathrm{aAB}}$ & $4.47 \pm 0.49^{\mathrm{aBC}}$ & $4.17 \pm 0.29^{\mathrm{bC}}$ & $4.00 \pm 0.10^{\mathrm{abC}}$ & $3.87 \pm 0.65^{\mathrm{abC}}$ & $2.70 \pm 0.70^{\mathrm{bD}}$ \\
\hline TW-ice & $5.87 \pm 0.90^{\mathrm{aA}}$ & $4.97 \pm 0.15^{\text {bcB }}$ & $4.70 \pm 0.26^{\mathrm{abC}}$ & $4.03 \pm 0.42^{\mathrm{abC}}$ & $3.73 \pm 0.25^{\mathrm{bCD}}$ & $3.07 \pm 0.55^{\mathrm{bcDE}}$ & $2.70 \pm 0.66^{\mathrm{bDE}}$ & $2.37 \pm 0.50^{\mathrm{bE}}$ \\
\hline SAEW & $5.87 \pm 0.42^{\mathrm{aA}}$ & $5.33 \pm 0.23^{\mathrm{abA}}$ & $3.97 \pm 0.70^{\mathrm{bcB}}$ & $3.13 \pm 0.78^{\mathrm{bcBC}}$ & $2.73 \pm 0.35^{\mathrm{cC}}$ & $2.73 \pm 0.15^{\mathrm{cC}}$ & & \\
\hline TW & $5.87 \pm 0.90^{\mathrm{aA}}$ & $4.53 \pm 0.65^{\mathrm{cB}}$ & $2.70 \pm 0.53^{\mathrm{cC}}$ & $2.70 \pm 0.53^{\mathrm{cC}}$ & $2.63 \pm 0.35^{\mathrm{cC}}$ & $1.63 \pm 0.70^{\mathrm{dC}}$ & & \\
\hline
\end{tabular}

Notes: (1) Mean values \pm standard deviations from triplicate are presented; (2) Means in the same column with different small letters are significantly different ( $p<0.05$ ); (3) Means in the same row with different capital letters are significantly different $(p<0.05)$. TW, tap water; SAEW, slightly acidic electrolyzed water.

The changes mentioned in hardness, gumminess, and chewiness could be attributed to changes in the proteins and lipids of the fish muscle tissue caused by enzyme reactions and bacterial reproduction $^{[19]}$. Based on the maintenance of texture by the combined treatment (SAEW+SAEW-ice), it is likely to deduce that the combination of SAEW and SAEW-ice could inhibit the changes in the protein, lipid, and microbial population, which corresponded with the results of the TVBN, TBA and TVC values. Relevant studies have mentioned that SAEW or SAEW-ice could improve the textural parameters and maintain aquatic product quality to some extent. Zhang et al. ${ }^{[19]}$ indicated that the combined treatment of ice-glazing with weakly acidic electrolyzed water (WAEW) and modified atmosphere packaging (MAP) effectively retarded the degradation of the physical structure of shrimp muscle and maintained its quality. In the previous study, an SAEW+AA treatment was shown to have a significant effect on maintaining a better texture of freshwater prawns during cold storage $^{[18]}$

\subsection{Sensory evaluation}

Sensory evaluation is crucial in food quality evaluation, which results in the consumers' final reaction ${ }^{[13,33]}$. The sensory scores of the pomfret samples were derived from appearance, color, odor and overall acceptability equally. As illustrated in Figure 6 and Figure 7, the sensory scores of all of the pomfrets continuously decreased with increasing storage time. Among the five groups, the SAEW+SAEW-ice group had a significantly higher level of sensory scores on the 12th day $(p<0.05)$. In general, the fish samples are regarded as unacceptable for human consumption at sensory scores below $4^{[22]}$. The sensory scores of the samples scored 3.15 and 3.80 on the 12th and 9th day in the SAEW and TW groups, respectively, which were lower than the critical value. At the end of storage (day 18), unacceptable samples were not found among the TW-ice, SAEW-ice, and SAEW+SAEW-ice groups. However, the sensory evaluation showed a retardance to a certain degree, compared with the microbiological and chemical analysis. In agreement with 
recent results reported by several authors ${ }^{[10,20]}$, this was possibly due to the sensory analysis likely not being sensitive enough. Nevertheless, we still concluded that the SAEW+SAEW-ice

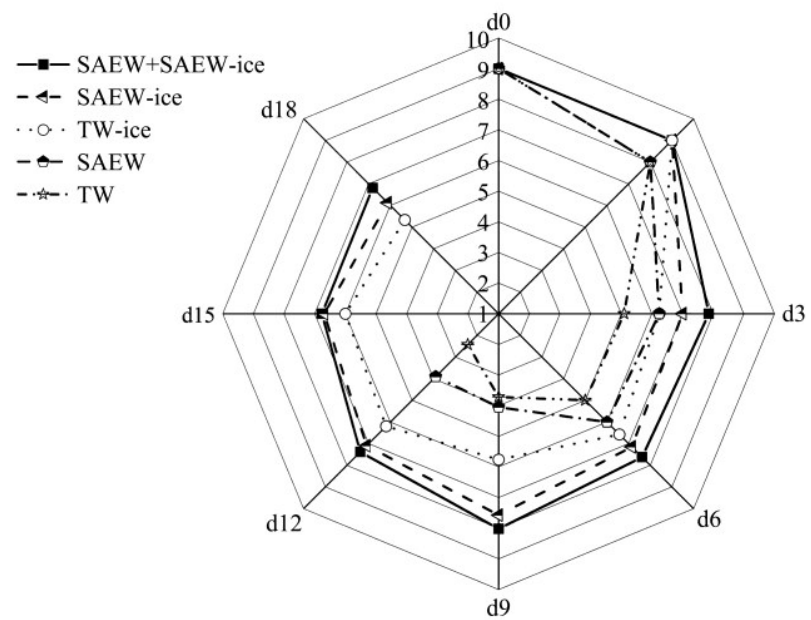

a. Appearance

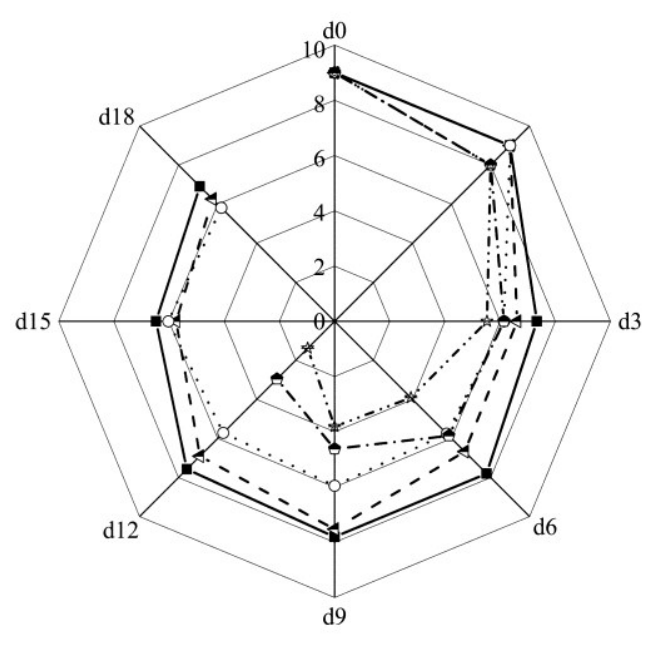

c. Color treatment exhibited a splendid ability for the preservation of pomfret, as the samples of this group maintained the lowest value within the 18-day storage period.

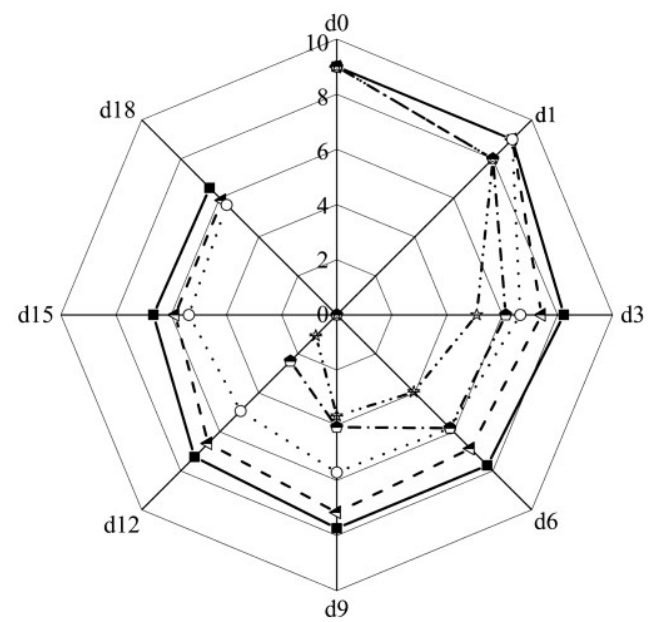

b. Smell

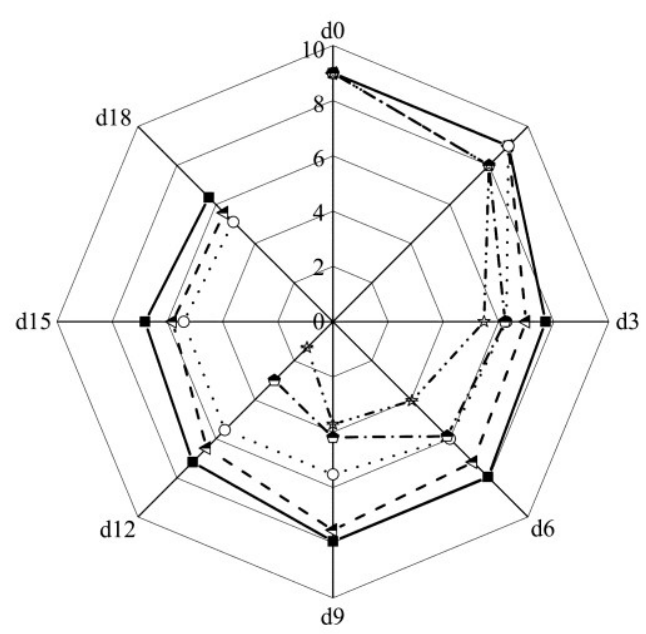

d. Overall acceptability

Figure 6 Radar plots of individual sensory evaluation

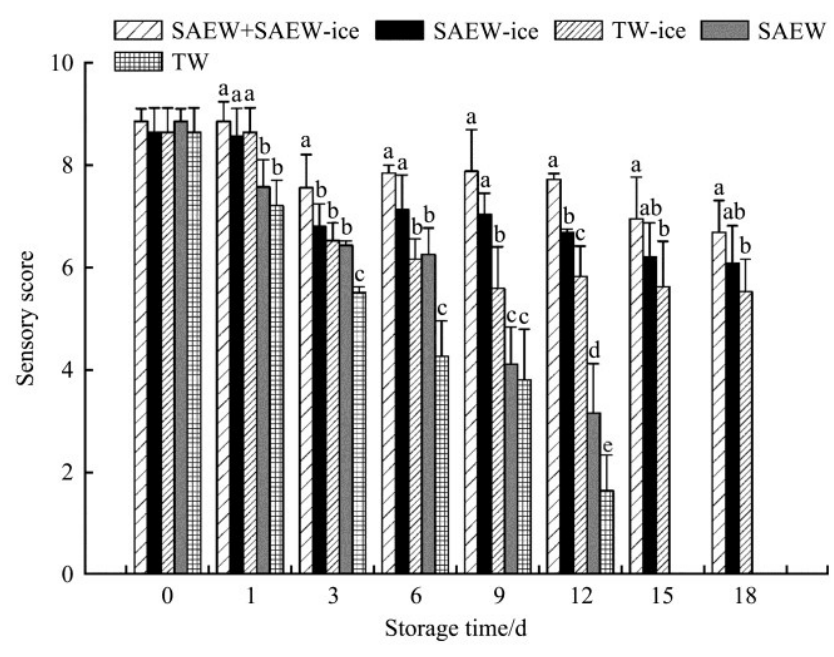

Note: Different lowercase letters at the same storage time showed a significant difference at $p<0.05$.

Figure 7 Changes in sensory quality of pomfrets with different treatments during cold storage

\section{Conclusions}

In this study, five storage methods (TW, SAEW, TW-ice,
SAEW-ice, and SAEW+SAEW-ice) were tested to evaluate their effects on the preservation of pomfrets. Based on the comparative analysis of the quality indexes (TVC, pH, TBA, TVBN, texture analysis and sensory properties), the combination of SAEW and SAEW-ice treatment was capable of reducing bacterial contamination and prolonging the shelf life of the pomfrets during storage at $4^{\circ} \mathrm{C}$ when compared with SAEW or SAEW-ice alone. Meanwhile, these results revealed that the treatments of SAEW and SAEW-ice also contributed to the preservation and storage of pomfrets. In a future study, the preservation effectiveness of SAEW and SAEW-ice in different concentrations and combinations on other types of seafood will be performed to lay the foundation for commercial application for the preservation of aquatic products.

\section{Acknowledgements}

This study was financially supported by the National Key Research and Development Program of China (Grant No. 2018YFD0701001; Grant No. 2017YFB0404000). Any opinions, findings, and conclusions expressed in this publication are those of the authors and do not necessarily reflect the views of Zhejiang University. 


\section{[References]}

[1] Zhao F, Zhuang P, Song C, Shi Z H, Zhang L Z. Amino acid and fatty acid compositions and nutritional quality of muscle in the pomfret, Pampus punctatissimus. Food Chemistry, 2010; 118(2): 224-227.

[2] Eliassona S, Arasonb S, Bjorn Margeirssona D, Bergssonc A B, Palsson O P. The effects of superchilling on shelf-life and quality indicators of whole Atlantic cod and fillets. LWT-food Science and Technology, 2019; 100: 426-434.

[3] Manju S, Srinivasagopal T, Jose L, Ravishankar C, Ashokkumar K. Nucleotide degradation of sodium acetate and potassium sorbate dip treated and vacuum packed Black Pomfret (Parastromateus niger) and Pearlspot (Etroplus suratensis) during chill storage. Food Chemistry, 2007; 102(3): 699-706.

[4] Fishery and Fisheries Administration Bureau of Ministry of Agriculture and Rural Areas of the People's Republic of China. China fishery statistical yearbook. Beijing: China Agricultural Press, 2019.

[5] Peng S, Gao Q, Shi Z, Zhang C, Wang J, Yin F, et al. Effect of dietary n-3 LC-PUFAs on plasma vitellogenin, sex steroids, and ovarian steroidogenesis during vitellogenesis in female silver pomfret (Pampus argenteus) broodstock. Aquaculture, 2015; 444: 93-98.

[6] Peng S M, Shi Z H, Fei Y, Gao Q X, Sun P, Wang J G. Effect of high-dose vitamin $\mathrm{C}$ supplementation on growth, tissue ascorbic acid concentrations and physiological response to transportation stress in juvenile silver pomfret, Pampus argenteus. Journal of Applied Ichthyology, 2013; 29(6): 1337-1341.

[7] Lorentzen G, Rotabakk B T, Olsen S H, Skuland A V, Siikavuopio S I. Shelf life of snow crab clusters (Chionoecetes opilio) stored at 0 and $4 \mathrm{C}$. Food Control, 2016; 59: 454-460.

[8] Soares N M F, Oliveira M S G, Vicente A A. Effects of glazing and chitosan-based coating application on frozen salmon preservation during six-month storage in industrial freezing chambers. LWT-Food Science and Technology, 2015; 61(2): 524-531.

[9] Sáez M I, Suárez M D, Martínez T F. Effects of alginate coating enriched with tannins on shelf life of cultured rainbow trout (Oncorhynchus mykiss) fillets. LWT, 2020; 118: 108767. doi: 10.1016/j.lwt.2019.108767.

[10] Bono G, Badalucco C. Combining ozone and modified atmosphere packaging (MAP) to maximize shelf-life and quality of striped red mullet (Mullus surmuletus). LWT, 2012; 47(2): 500-504.

[11] Monteiro M L G, Marsico E T, Mano S B, da Silveira Alvares T, Rosenthal A, Lemos M, et al. Combined effect of high hydrostatic pressure and ultraviolet radiation on quality parameters of refrigerated vacuum-packed tilapia (Oreochromis niloticus) fillets. Sci Rep., 2018; 8(1): 9524 . doi: 10.1038/s41598-018-27861-9.

[12] Wu C H, Hu Y Q, Chen S G, Chen J C, Liu D H, Ye X Q. Formation mechanism of nano-scale antibiotic and its preservation performance for silvery pomfret. Food Control, 2016; 69: 331-338.

[13] Alexi N, Byrne D V, Nanou E, Grigorakis K. Investigation of sensory profiles and hedonic drivers of emerging aquaculture fish species. J Sci Food Agr., 2018; 98(3): 1179-1187.

[14] Rahman S M E, Khan I, Oh D H. Electrolyzed water as a novel sanitizer in the food industry: Current Trends and Future Perspectives. Comprehensive Reviews in Food Science and Food Safety, 2016; 15(3): 471-490.

[15] Ngnitcho P F K, Tango C N, Khan I, Daliri E B M, Chellian R, Oh D H. The applicability of Weibull model for the kinetics inactivation of Listeria monocytogenes and Escherichia coli O157: H7 on soybean sprouts submitted to chemical sanitizers in combination with ultrasound at mild temperatures. LWT, 2018; 91: 573-579.

[16] Hao J, Wu T, Li H, Liu H. Differences of bactericidal efficacy on Escherichia coli, Staphylococcus aureus, and Bacillus subtilis of slightly and strongly acidic electrolyzed water. Food and Bioprocess Technology,
2016; 10(1): 155-164.

[17] Kim H J, Tango C N, Chelliah R, Oh D H. Sanitization efficacy of slightly acidic electrolyzed water against pure cultures of Escherichia coli, Salmonella enterica, Typhimurium, Staphylococcus aureus and Bacillus cereus spores, in comparison with different water hardness. Sci Rep., 2019; 9(1): 4348. doi: 10.1038/s41598-019-40846-6.

[18] Yan W, Zhang Y, Yang R, Zhao W. Combined effect of slightly acidic electrolyzed water and ascorbic acid to improve quality of whole chilled freshwater prawn (Macrobrachium rosenbergii). Food Control, 2020; 108: 106820. doi: 10.1016/j.foodcont.2019.106820.

[19] Zhang B, Ma L K, Deng S G, Xie C, Qiu X H. Shelf-life of pacific white shrimp (Litopenaeus vannamei) as affected by weakly acidic electrolyzed water ice-glazing and modified atmosphere packaging. Food Control, 2015; 51: 114-121.

[20] Xuan X T, Fan Y F, Ling J G, Hu Y Q, Liu D H, Chen S G, et al. Preservation of squid by slightly acidic electrolyzed water ice. Food Control, 2017; 73: 1483-1489.

[21] Buege J A, Aust S D. Microsomal lipid peroxidation. Methods in enzymology, 1978; 52: 302-310.

[22] Wu C, Fu S, Xiang Y, Yuan C, Hu Y, Chen S, et al. Effect of Chitosan Gallate coating on the quality maintenance of refrigerated $\left(4^{\circ} \mathrm{C}\right)$ silver pomfret (Pampus argentus). Food and Bioprocess Technology, 2016; 9(11): 1835-1843.

[23] Foss. Determination of total volatile basic nitrogen of fresh fish and frozen fish. Application Sub Note, 2002; 8(16).

[24] Luan L, Wu C, Wang L, Li Y, Ishimura G, Yuan C, et al. Protein denaturation and oxidation in chilled hairtail (Trichiutus haumela) as affected by electrolyzed oxidizing water and chitosan treatment. International Journal of Food Properties, 2018; 20(Supp.3): S2696-S2707.

[25] Zhao L, Zhang Z, Wang M, Sun J, Li H, Malakar P K, et al. New insights into the changes of the proteome and microbiome of shrimp (litopenaeus vannamei) stored in acidic electrolyzed water ice. J Agric Food Chem, 2018; 66(19): 4966-4976.

[26] Xu G, Tang X, Tang S, You H, Shi H, Gu R. Combined effect of electrolyzed oxidizing water and chitosan on the microbiological, physicochemical, and sensory attributes of American shad (Alosa sapidissima) during refrigerated storage. Food Control, 2014; 46: 397-402.

[27] Vieira B B, Mafra J F, da Rocha Bispo A S, Ferreira M A,de Lima Silva F, Rodrigues A V N, et al. Combination of chitosan coating and clove essential oil reduces lipid oxidation and microbial growth in frozen stored tambaqui (Colossoma macropomum) fillets. LWT, 2019; 116: 108546. doi: 10.1016/j.lwt.2019.108546.

[28] Gill O C. Meat spoilage and evaluation of the potential storage life of fresh meat. Journal of Food Protection, 1983; 46: 444-448.

[29] Trigo M, Rodríguez A, Dovale G, Pastén A, Vega-Gálvez A, Aubourg S P. The effect of glazing based on saponin-free quinoa (Chenopodium quinoa) extract on the lipid quality of frozen fatty fish. LWT, 2018; 98: 231-236.

[30] Miranda J M, Ortiz J, Barros-Velázquez J, Aubourg S P. Quality enhancement of chilled fish by including alga Bifurcaria bifurcata extract in the icing medium. Food and Bioprocess Technology, 2015; 9(3): 387-395.

[31] Feng X, Bansal N, Yang H S. Fish gelatin combined with chitosan coating inhibits myofibril degradation of golden pomfret (Trachinotus blochii) fillet during cold storage. Food Chemistry, 2016; 200: 283-292.

[32] Feng X, Ng V K, Mikš-Krajnik M, Yang H. Effects of fish gelatin and tea polyphenol coating on the spoilage and degradation of myofibril in fish fillet during cold storage. Food and Bioprocess Technology, 2016; 10(1): 89-102.

[33] Ishimura G, Bailey M. The market value of freshness: observations from the swordfish and blue shark longline fishery. Fisheries Science, 2013; 79(3): 547-553. 